\title{
Influence Research of Capital Structure on Performance of Listed Real Estate Enterprises in China
}

\author{
Xinxin Jing ${ }^{1, \text { a }}$ \\ ${ }^{1}$ School of Finance, Zhongnan University of Economics and Law, Wuhan, 430000, China
}

Keywords: Assets liabilities ratio, EVA, Financing model, Inverse U-shaped structure

\begin{abstract}
Since the implementation of commercial housing reform, the real estate industry has entered a stage of rapid development. As the real estate industry takes up a large amount of capital, it is becoming the pillar industry of our country. In this paper, the regression model of two-stage panel is used to analyze the impact of capital structure on the performance of real estate management. The paper comprehensively utilizes the data of Shenzhen, Shanghai and Hongkong listed real estate enterprises, makes an empirical study on the influence of capital structure on the management performance of the real estate enterprises, and obtains the transformation of management performance of the real estate enterprises in different conditions of capital structures. It verifies the inverse U-shaped structure of the capital structure on the management performance of the real estate enterprises and obtains the optimal interval result of the capital structure ranges from $60 \%$ to $85 \%$. According to the current situation of the capital structure of the listed real estate enterprises in China, we also conclude that the Asset liability ratios of the enterprises are relatively low.
\end{abstract}

\section{Introduction}

The real estate industry is a capital-intensive industry, and the occupation and circulation of the funds of the real estate projects are very important aspects of the real estate enterprises. All the development activities and other economic activities of the real estate industry need a lot of money to operate. The listed real estate enterprises can raise money from different financing channels and using different financing methods. Different sources, methods and deadlines of the funds can form different financing structure and decisions. According to the characteristics of the capital structure of listed real estate enterprises in our country, this paper analyzes the problems existing in the financing of real estate enterprises in China, such as the preference of equity financing and the inefficiency of enterprises.

\section{Literature Review and Problems Raised}

Influence of Debt Structure on Enterprise Performance. We summarize the foreign scholars' research on relevant theories, and we can find that the impact of debt structure on corporate performance is not only on one aspect, but also the comprehensive results of two aspects. The influence of debt structure on enterprise performance has not formed a completely consistent view in the domestic related researches. In the domestic research, there are still the third perspective, namely, there is no significant linear relationship between the corporate debt structure and firm performance, but there is a significant nonlinear relationship.

Influence of Equity Structure on Enterprise Performance. In foreign research, there is no consistent conclusion about the relationship between the ownership structure and the firm performance. In the process of reviewing the relevant research findings of domestic scholars, we can find that the researches of the relevant content are quite rich. The researches on equity structure can be divided into two categories, representing the ownership structure variables of ownership structure and equity ownership concentration. The research results are relatively consistent in the study of 
equity concentration in the relevant researches. The more concentrated the Equity Structure is, the higher the enterprise's operating performance is.

\section{Empirical Results of Influence of Capital Structure on Performance of Listed Real Estate Enterprises in China}

Research Methods, Variables Selection and Model Design. The paper collected the data of the listed real estate enterprises in China and established the relationship models of the relevant variables. The paper selected the two-stages panel regression model, utilized the E software to analyze the data and verified the models.

We have:

$$
\begin{aligned}
& R O M_{i, t}=\alpha i, t+\beta 1 D A R i, t+\varepsilon i, t \\
& R O M_{i, t}=\alpha i, t+\beta 1 D A R i, \quad t+\beta 2 C S P i, t+\varepsilon i, t \\
& R O M_{i, t}=\alpha i, t+\beta 1 D A R i, \quad t+\beta 2 C S P i, t+\beta 3 G R i, t+\varepsilon i, t \\
& R O M_{i, t}=\alpha i, t+\beta 1 D A R i, \quad t+\beta 2 C S P i, t+\beta 3 S Z i, t+\varepsilon i, t
\end{aligned}
$$

Among them, i represents the number of the panels and t represents time. Through the analysis of the two-stages panel, we calculated the coefficients of the independent variables of DAR, CSP, SZ, GR and CA.

Analysis and Results of Empirical Models. First, we studied the significance of the explanation variable of Asset liability ratio. We use the E software to analyze the equation 3.1 using the regression method. The results are as follows.

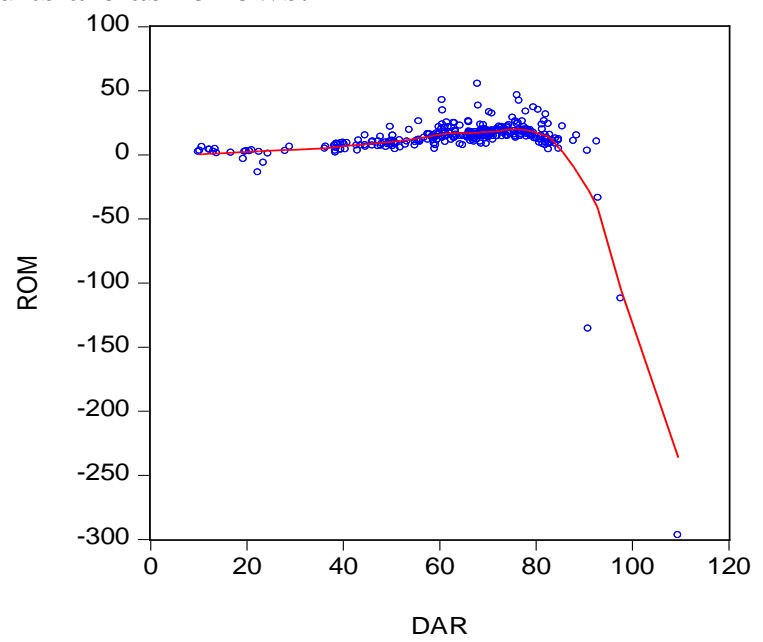

Figure 1. Dispersive points charts and fitting curve

We can know that the Asset liability ratio and the yield rate of net asset are not a liner relationship from the perspective of the dispersive points charts and fitting curve.

Table 1. Empirical results of model 3-1 analysis

\begin{tabular}{lcccc}
\hline \multicolumn{1}{c}{ Variable } & Coefficient & Std.Error & t-Statistic & Prob \\
\hline C & 13.85793 & 4.93298 & 2.809241 & 0.0053 \\
DAR & -0.024728 & 0.07532 & -0.32827 & 0.7429 \\
F- Statistic & 0.107761 & \\
R $^{2}$ (R-squared) & & 0.000361 & \\
Prob (F-statistic) & & 0.742938 & \\
\end{tabular}

According to the data in Table 1, the empirical results of model 3-1 reflects the negative correlation between the Asset liability ratio and the return rate of net asset. 
We modified the equation 3.1 according to the speculation:

$$
R O M_{i, t}=\alpha i, t+\beta 1 D A R i, t+\beta 2 D A R^{\wedge 2}{ }_{i, t}+\varepsilon i, t
$$

We use the E software to analyze the 3.6 using the regression method. The results are as follows. Table 2. Empirical results of model 3-6 analysis

\begin{tabular}{|c|c|c|c|c|}
\hline Variable & Coefficient & Std. Error & t-Statistic & Prob \\
\hline $\mathrm{C}$ & -50.42004 & 8.076916 & -6.242486 & 0.0000 \\
\hline $\mathrm{DAR} \wedge 2$ & -0.025030 & 0.002654 & -9.431485 & 0.0000 \\
\hline DAR & 2.694726 & 0.295838 & 9.108793 & 0.0000 \\
\hline F- Statistic & \multicolumn{4}{|c|}{44.54624} \\
\hline $\mathrm{R}^{2}$ (R-squared) & \multicolumn{4}{|c|}{0.230754} \\
\hline Prob (F-statistic) & \multicolumn{4}{|c|}{0.000000} \\
\hline
\end{tabular}

It can be proved that the previous guess of the inverse U-shaped relationship between the return on assets and the asset liability ratio, which has obvious significance. Then the model 3.1 is transformed into model 3.6 and the model 3.2 is also transformed into the equation as follows:

$$
\operatorname{ROM}_{i, t}=\alpha i, t+\beta 1 D A R i, t+\beta 2 D A R_{i, t}^{\wedge}+\beta_{3} C S P i, t+\varepsilon i, t
$$

The equation 3.6 was analyzed by regression using $E$ software. The regression results are showed as follows:

Table 3. Empirical results of model 3-6 analysis

\begin{tabular}{ccccc}
\hline Variable & Coefficient & \multicolumn{1}{c}{ Std. Error } & t-Statistic) & \multicolumn{1}{c}{ Prob } \\
\hline C & -61.06617 & 11.26583 & -5.420476 & 0.0000 \\
DAR^2 & -0.03177 & 0.003602 & -8.821479 & 0.0000 \\
DAR & 3.195670 & 0.391745 & 8.157526 & 0.0000 \\
CSP & 0.080226 & 0.064659 & 1.240751 & 0.2165 \\
F- Statistic & 27.30497 & & & \\
$\mathrm{R}^{2}$ (R-squared) & 0.337217 & & & \\
Prob (F-statistic) & 0.000000 & & & \\
\hline
\end{tabular}

The equation 3.7 was analyzed by regression using E software. The regression results are showed as follows: 
Table 4. Empirical results of model 3-7 analysis

\begin{tabular}{ccccc}
\hline Variable & Coefficient & Std. Error & t-Statistic & Prob \\
\hline C & -37.04288 & 14.91707 & -2.483254 & 0.0140 \\
DAR^2 & -0.031508 & 0.003551 & -8.872175 & 0.0000 \\
DAR & 3.138963 & 0.386734 & 8.116599 & 0.0000 \\
CSP & 0.006915 & 0.002868 & 2.410976 & 0.00170 \\
CSP^2 & -0.797421 & 0.369555 & -2.157786 & 0.0324 \\
F- Statistic & & 22.54411 & & \\
$\mathrm{R}^{2}$ (R-squared) & & 0.360451 & & \\
Prob (F-statistic) & & 0.000000 & & \\
\hline
\end{tabular}

According to the classifications of the samples, we ascertained the final three models as follows:

$$
\begin{aligned}
& R O M_{i, t}=\alpha i, t+\beta 1 D A R i, t+\beta 2 D A R_{i, t}^{\wedge 2}+\varepsilon i, t \\
& R O M_{i, t}=\alpha i, t+\beta 1 D A R i, t+\beta 2 D A R_{i, t}^{\wedge 2}+\beta_{3} C S P^{\wedge} i, t+\beta_{4} C S P i, t+\varepsilon i, t \\
& R O M_{i, t}=\alpha i, t+\beta 1 D A R i, t+\beta 2 D A R_{i, t}^{\wedge 2}+\beta_{3} G R i, t+\beta_{4} S Z i, t+\varepsilon i, t
\end{aligned}
$$

According to the process of the empirical analysis, the model 3.5 reflects the inverse U-shaped relationship between the Asset liability ratio and the return rate of net asset. The optimal interval of the capital structure ranges from $60 \%$ to $85 \%$.

\section{Conclusions and Prospects}

Research Conclusions. In the implementation of engineering ethics in the process of educational reform, we should actively absorb the international advanced experience of engineering ethics education, expand the international perspective, and actively participate in the international. By using the two-stage panel regression model, the paper draws the conclusion of the inverse U-shaped structure of the asset liability ratio on the management performance of the listed real estate enterprises and verifies the optimal basic structure indeed exists. The conclusion has a solid theoretical foundation, and is consistent with the conclusion of the trade-off theory in the modern capital structure theory. This paper not only verifies the existence of the optimal capital structure interval, but also obtains the optimal interval of capital structure of Chinese listed real estate enterprises on the basis of samples ranges from $60 \%$ to $85 \%$. In the descriptive statistics of the asset liability ratio of the listed real estate enterprises, the asset liability ratio has just reached over $60 \%$, which shows that the proportion of debt financing in China's real estate market is relatively low.

Countermeasures and Suggestions. The above empirical analysis shows that listed real estate companies do have an optimal capital structure, making the performance of enterprises largest. Therefore, the real estate enterprises should constantly adjust their capital structure to maintain the capital structure in the optimal interval. The main recommendations include: curbing the equity financing preferences of real estate companies, vigorously developing the bond market, improving the bankruptcy mechanism and encouraging innovative financing channels of real estate enterprises. 


\section{References}

[1] Chen Xiaoyue, Xu Xiaodong. Equity Structure , Firm Performance and the Protection for Investers' Interest [J]. Economic Research Journal, 2001(11): 3-11+94.

[2] Frank,M.Z.,Goyal,V.K. Testing the pecking order Theory of Capital Structure [J].Journal of Financial Economics, 2003,(67): 217-248.

[3] Durnev,A.,E.Kim. To Steal or not to Steal :Firm Attributes, Legal Environment and Valuation [J]. Journal of Finance, 2005,(60): 1461-1493.

[4] Panayotis Kapopoulos,Sophia Lazaretou. Corporate Ownership Structure and Firm Performance: evidence from Greek firms [J].Corporate Governance: An International Review, 2007,(15): 144-158.

[5] Tee Chwee Ming ,Chan Sok Gee. The Influence of Ownership Structure of the Corporate Performance of Malaysian Public Listed Companies [J]. ASEAN Economic Bulletin, 2008,(25): 95-208.

[6] Shleifer,Andrei, Robbert Vishny. A Survey of Corporate Goverance [J].Journal of Finance, 1997,(52): 737-783.

[7] Jianjun Miao. Optimal Capital Structure and Industry Dynamics [J]. Journal of Finance, 2005,(6): 2621-2626.

[8] Holderness,C.G., D.P.Sheehan. The Role of Majority Shareholders in Publicly Held Corporations: An exploratory analysis [J]. Journal of Financial Economics, 1988, (20):317-346.

[9] Hamid Mehran. Executive Compensation Structure, Ownership and Firm Performance [J]. Journal of Financial Economics, 1995,(38): 163-184.

[10] Joseph, T.L. The Determinants of Capital Structure Evidence on UK Property Companies [J]. Journal of Property Investment \& Finance, 1999,(18): 316-331.

[11] Michel,A.Habib. Monitoring, Implicit Contracting,and the Lack of Permanence of Leveraged Buyouts [J].European Finance Review, 1997,(1): 139-163. 